\title{
Active Versus Passive Academic Networking Evidence from Micro-Level Data
}

\author{
Goel, Rajeev K.; Grimpe, Christoph
}

Document Version

Accepted author manuscript

Published in:

Journal of Technology Transfer

DOI:

10.1007/s10961-011-9236-5

Publication date:

2013

License

Unspecified

Citation for published version (APA):

Goel, R. K., \& Grimpe, C. (2013). Active Versus Passive Academic Networking: Evidence from Micro-Level

Data. Journal of Technology Transfer, 38(2), 116-134. https://doi.org/10.1007/s10961-011-9236-5

Link to publication in CBS Research Portal

\section{General rights}

Copyright and moral rights for the publications made accessible in the public portal are retained by the authors and/or other copyright owners and it is a condition of accessing publications that users recognise and abide by the legal requirements associated with these rights.

Take down policy

If you believe that this document breaches copyright please contact us (research.lib@cbs.dk) providing details, and we will remove access to the work immediately and investigate your claim. 


\title{
Active Versus Passive Academic Networking: Evidence from Micro-Level Data
}

\author{
Rajeev K. Goel, and Christoph Grimpe
}

Journal article (Post print version)

This article was originally published in The Journal of Technology Transfer, Vol. 38, Nr. 2, Pages $116-134$.

First published online October 16, २011.

The final publication is available at Springer via http://dx.doi.org/10.1007/s10961-011-9236-5.

Uploaded to Research@CBS: March 2016 


\title{
Active versus Passive Academic Networking: Evidence from Micro-Level Data
}

\author{
RAJEEV K. GOEL* \\ Illinois State University (USA) \\ CHRISTOPH GRIMPE \\ Copenhagen Business School (Denmark)
}

Published in the Journal of Technology Transfer, Vol. 38(2), 116-134. The final version can be found at http://link.springer.com/article/10.1007\%2Fs10961-011-9236-5

KEYWORDS: Academic networking; Conferences; Patents; Publications; University; Germany

JEL CLASSIFICATION: O3; L3

* Corresponding author. Address: Department of Economics, Illinois State University, Normal, IL 617904200, USA. Phone: +1-309-438-2360; Fax: +1-309-438-5228; E-mail: rkgoel@ilstu.edu. We appreciate comments by two referees and the editor, $\mathrm{Al}$ Link. 


\title{
Active versus Passive Academic Networking: Evidence from Micro-Level Data
}

\begin{abstract}
This paper examines determinants of networking by academics. Using information from a unique large survey of German researchers, the key contribution focuses on the active versus passive networking distinction. Is active networking by researchers a substitute or a complement to passive networking? Other contributions include examining the role of geographic factors in networking and whether research bottlenecks affect a researcher's propensity to network. Are the determinants of European conference participation by German researchers different from conferences in rest of the world? Results show that some types of passive academic networking are complementary to active networking, while others are substitute. Further, we find differences in factors promoting participation in European conferences versus conferences in rest of the world. Finally, publishing bottlenecks as a group generally do not appear to be a hindrance to active networking. Implications for academic policy are discussed.
\end{abstract}




\section{Active versus Passive Academic Networking: Evidence from Micro-Level Data}

\section{Introduction}

Insights into the process of research and science have intrigued researchers and policymakers for several decades (see Merton (1973) for seminal work in this area). Within this broad context, a number of aspects have been studied, including the publishing and patenting behavior of scientists, the behavior of journal editors, the outside links of academics to industry, etc. However, the networking behavior of academics has received relatively little attention, due in part to a lack of adequate data. This issue is nevertheless quite important both from an academic and from a policy perspective for several reasons.

Academic research is often driven or inspired by networks of scientists collaborating to achieve a common goal (e.g., Defazio et al. (2009)). Such networking by entrepreneurial academics that may be a precursor to actual collaboration can take numerous forms and has several personal and external benefits. For example, networking enables researchers to reach a greater number of peers than otherwise, which in turn makes cutting edge research more accessible and enables researchers to publicize their own new ideas (and thereby obtain citations to their work (see Hudson (2007))). Further, networking might enable networked researchers to obtain invitations to conferences and might even improve publication odds at professional journals (see Goel and Faria (2010), Macdonald and Kam (2007), Laband and Piette (1994), Medoff (2003)). Organizations that researchers are associated with (e.g., universities, laboratories, institutes, etc.) benefit 
from greater networking via reputation enhancement, and they encourage networking by subsidizing such endeavors directly (travel costs for attending conferences) and indirectly (release time for conference attendance). In sum, understanding the determinants of why researchers engage in academic networking is important as it provides insights into the process of research that can be used by policy making in order to increase the efficiency and productivity of a science system, for example through reconsidering grant and reward mechanisms in academia.

At a finer level of detail, academic networking may be active or passive from the researchers' perspective. Some networking, such as going to conferences, is consciously (endogenously) undertaken by academics by spending time and money, weighing the relative costs and benefits. Some academics, conversely, might passively become associated with networks - either by obtaining degrees from large reputed educational institutions (see Kocher and Sutter (2001)) or by collaborating with a well-known, highly networked researcher (Medoff (2003)). A researcher graduating from a well-known university or one who happens to collaborate with a well-known senior researcher is connected/networked to a larger pool of researchers, even without consciously expending efforts to network. While the benefits of both passive and active networking are likely to be similar, their determinants can vary. Also, by design passive networking is exogenous and its costs are indirect. In this paper, we aim at contributing to the literature by examining the determinants of active networking and how it relates to passive networking, a topic relatively understudied. In fact, a few scholars have investigated aspects of networking, mainly in the context of university entrepreneurship (see Cooper et al. (in press), Koschatzky (2002)). Moreover, a number of scholars have examined the 
role of academic networks (notable examples include Crane (1965), Goel and Faria (2010), Hudson (2007), Klamer and Van Dalen (2001), and Merton (1973)). ${ }^{1}$ The distinction between active versus passive networking has however largely not been formally flushed out. ${ }^{2}$ Are active and passive academic networking related and, if yes, how?

Hence, this research examines the determinants of academic networking while taking account of the active versus passive networking distinction. Specifically, using information from a unique large survey of German researchers, we examine the determinants of active academic networking (denoted by conference participation), while simultaneously examining whether active and passive networking (denoted by size of peer group at an institution, and academic discipline) are substitutes or complements. Is active networking by researchers a substitute or a complement to passive networking? Moreover, we pay attention to the role of geographic space and how it affects networking patterns (Anselin et al. (1997), Jaffee et al. (1993)), and whether research bottlenecks affect a researcher's propensity to network. In this respect, we analyze whether the determinants of local conference participation (i.e., European) by German researchers are different from distant conferences (i.e., other countries outside Europe). This distinction is important because greater distance might also be associated with greater novelty of the knowledge conveyed and of connections to other researchers made. Besides the importance of our results for policy making, they could be relevant for the process of

\footnotetext{
1 Reviews of the broader literature on the economics of publishing can be found in Audretsch et al. (2002), Coupè (2004), Ellison (2002), Goel and Rich (2005), Goyal et al. (2006) and Stephan (1996).

2 Perhaps the closest work is by Faria and Goel (2010) whose setup recognizes the active-passive networking distinction, before proceeding to theoretically examine the effects of passive networking.
} 
resource allocation at academic institutions. For instance, if some passive networking and active networking turn out to be substitutes, then perhaps some resources promoting active networking could be allocated elsewhere.

The remainder of our paper is organized as follows. We move next to a discussion of the framework before the empirical methods are presented in section 3. Section 4 follows, describing the results, before turning to conclusions.

\section{The model}

To provide a foundation for the empirica analysis, we sketch a model of researchers' behavior. Drawing on Faria and Goel (2010) who model a game between academic authors and journal editors, the representative academic author's utility $(U)$ can be seen as a function of the number of publications $(q)$ and patents $(p)$, since these output measures are positively related to job promotions and remunerations. While some behavioural aspects of games are not easily amenable to empirical estimation, the rudimentary model informs our broader empirical analysis below.

There are network externalities generated by an author's academic network membership, $z>0$, with equilibrium $z^{*}=z(p, q ; m)$, where $m$ is passive networking. If the author is not a member of a network, $z=0$. This networking might be actively sought by going to professional conferences or might be passively acquired - for example, by the size of the peer group (academic department size). Other things being the same, there are more citations over time for networked authors $(z>0)$. Further, journal editors can have a taste for discrimination. The editors may be biased in favor of authors with a specific related network membership, or alternatively, the editors may be fair and practice 
no editorial favoritism (Laband and Piette (1994), Medoff (2003)).

Since networking by academics is generally not an end in itself but a means to an end - that is, an increase in professional stature (see Taylor et al. (2006)) - it is possible that there are some reverse feedbacks from networking to publications. ${ }^{3}$ However, we try to mitigate this possibility in our empirical analysis by taking stock of researchers' past publications (instead of current publications) as a regressor.

A researcher's propensity to network is determined by his/her personal attributes (professional experience (see Merton (1973)), gender (Corley and Gaughan (2005), Rosa and Dowson (2006), Thursby and Thursby (2005))), and professional attributes (publications $(q)$, patents $(p)$, external funding received, tenure). For instance, experienced researchers might already have built up a sufficient stature that they might feel relatively less need to actively network. Further, networking behavior of active researchers (i.e., those with many publications or patents) might be different than that of less active researchers.

Formally, the empirical analysis below will aim to determine the signs of the derivatives $(\partial z / \partial q)$ and $(\partial z / \partial p)$, in addition to ascertaining whether the two signs are in the same direction.

Turning to a different dimension of networking, passive networking (captured in our sample below by (i) university employment; (ii) academic discipline; (iii) research group leadership; and (iv) size of the peer group) might be a substitute or complement to active networking/conference participation. While one could argue that an academic exerts some effort in seeking university employment, choosing one's academic discipline or in

\footnotetext{
${ }^{3}$ While it is conceivable that patents also have simultaneity issues with networking, the lags associated with patent grants largely make them predetermined.
} 
acquiring research leadership, the primary inducements for such efforts are not likely to attain greater networking. Rather, one becomes part of a certain network after being at a certain university (Ivy League) or in a certain academic discipline (e.g., association of chemical engineers). Hence, our classification of these factors under passive networking seems reasonable.

Universities enable formation of research networks that are more voluntary on the part of the researcher, compared to the private sector (Goel and Rich (2005)). Thus university researchers might have different demands to network with outside researchers than their counterparts in research laboratories. Additionally, passive networks in hard science disciplines might be differently related to active networking than those in social sciences. Research group leaders have more resources at their disposal to spend on active networking, although their time commitments might prevent them from travelling to more distant places.

Finally, inducements to participate in conferences might emerge due to research bottlenecks such as inability to gain access to others' research, a small peer group or a lack of international cooperation (see Laband and Tollison (2000)). For instance, a large internal peer group diminishes the need for one to actively seek outside commentators/collaborators - for example in case of large academic departments with several researchers in a subfield versus small academic departments with one researcher in each subfield. Does an inability to gain access to others' research or inability to forge international collaborations induce one to attend more conferences?

Given this background, we empirically examine the determinants of active 
networking denoted by conference participation. ${ }^{4}$ We examine the influence of geographic dimension by examining separately the conference participation by German researchers in Europe (EU) versus outside Europe (i.e., in the rest of the world, ROW). The empirical model takes the following general form (with subscript $i$ denoting the type of active networking, $j$ capturing the personal attribute measure of the academic, $k$ denoting professional attribute type, $m$ denoting the type of passive networking measure and $n$ representing the type of publishing bottleneck)

Active networking by researchers $(z)_{i}=f\left(\right.$ Personal attributes $_{j}$, Professional attributes $k$,

$$
\begin{aligned}
& \text { Passive networking } m \text {, Publishing bottlenecks })_{n} \quad(1)^{5} \\
& \text { Conferences Total } \\
& j=\text { Experience, Gender } \\
& k=\text { Publications (q), Patents (p), External } \\
& \text { funding, Tenured } \\
& m=\text { University employment, Discipline, } \\
& \text { Research group leadership } \\
& n \quad=\text { No access to others } \text { research, } \\
& \text { International cooperation, Size of peer group }
\end{aligned}
$$

\footnotetext{
${ }^{4}$ Given appropriate data, one could consider other dimensions of active networking such as subscription to specific internet blog groups.

5 Admittedly, our classification of determinants in various subgroups is somewhat arbitrary. However, in the absence of specific guidance from the literature, the choice of classifications, while not necessarily unique, seems logical and intuitive.
} 
The variables used in Equation (1) are described in Table 2 and Figure 1 provides an exposition of the estimated model. We turn next to a discussion of the data employed and the estimation procedure used.

Figure 1: Conceptual model: Determinants of active networking

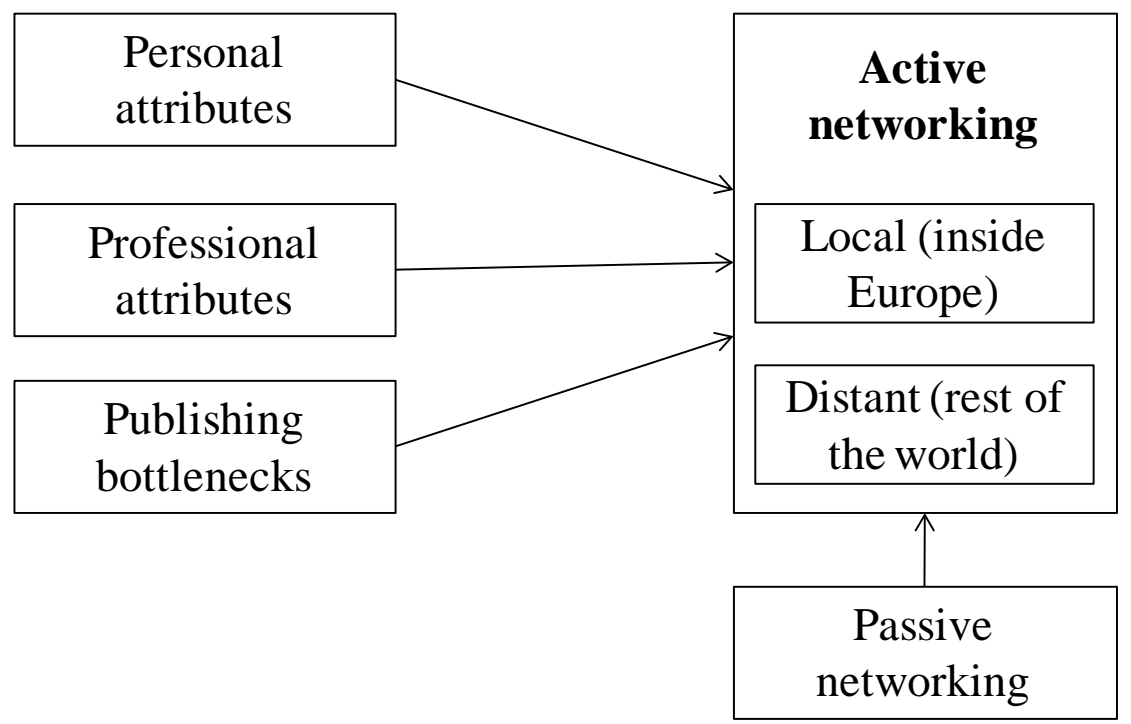

\section{Methods}

\subsection{Data}

Equation (1) is estimated using data from a micro-level survey conducted in 2008 among researchers in public science in Germany. Data were collected through an online questionnaire within a research project on behalf of the German Federal Ministry of Education and Research (Grimpe and Fier (2010)). The aim of the research project was to investigate scientists' involvement in the EU's 6th Research Framework Programme and to what extent scientists made use of other funding instruments available to them (BMBF, 2009). The questions used in this study were mostly taken from the general part appearing at the end of the questionnaire. Besides universities, a considerable share of 
public research in Germany is carried out at public research organizations (PRO), most notably at the major large German science organizations: Fraunhofer Society, Helmholtz Association, Leibniz Association and Max Planck Society. The gross sample was thus compiled using two sources: (1) a database called "Hochschullehrerverzeichnis" listing German university professors and academic personnel holding a $\mathrm{PhD}$ with their names, degrees and partly contact information; (2) an internet search of the PRO institutes' websites. Both sources led to a gross sample size of 16,269 researchers with an available e-mail address. In total, 2,797 responses with at least one question answered were obtained, corresponding to a response rate of 17.2 percent which is comparable to other online surveys of academics in Germany (e.g., Edler et al. (2011)). Due to missing values in some of the variables under study here, we end up with a final sample of 897 observations. ${ }^{6}$

To investigate whether our sample represents the population of scientists in Germany, we obtained data from the German Federal Ministry for Education and Research on the distribution of scientists across scientific disciplines, aggregated into four groups of scientific fields: natural sciences (e.g., chemistry, physics, mathematics), life sciences (e.g., medicine, biology, plant sciences), engineering sciences (e.g., process, chemical, or construction engineering), and social sciences and humanities. The groups are based on the classification used by the German Science Foundation. Table 1 compares the distribution of academics across the fields of study in Germany with our sample, drawing a distinction between scientists working at a university and those working at a PRO. This

\footnotetext{
${ }^{6}$ The difference between the number of responses received and observations used in the analysis can be attributed mainly to the following reason. Online surveys typically feature a large number of respondents who $\log$ in to the system but only respond to one or a few questions before dropping out. Nevertheless, they are counted by the system as "response" although the resulting observation is not usable.
} 
structural distinction can have important implications for researcher conduct (Goel and Rich (2005)).

Table 1: Distribution of academic scientists across disciplines in Germany (2005)

\begin{tabular}{lllll}
\hline & $\begin{array}{l}\text { Share university } \\
\text { scientists }\end{array}$ & $\begin{array}{l}\text { Share PRO } \\
\text { scientists }\end{array}$ & $\begin{array}{l}\text { Share total } \\
\text { scientists }\end{array}$ & Realized sample \\
\hline Natural sciences & 23.95 & 57.78 & 32.06 & 30.77 \\
Engineering sciences & 15.94 & 28.61 & 18.97 & 18.73 \\
Life sciences & 30.36 & 7.17 & 24.80 & 30.32 \\
Social sciences and humanities & 29.75 & 6.44 & 24.17 & 20.18 \\
Total & 100.00 & 100.00 & 100.00 & 100.00 \\
\hline $\begin{array}{l}\text { Source: Federal Ministry of Education and Research (BMBF), 2008; authors' calculations. All figures are } \\
\text { in percentages. }\end{array}$
\end{tabular}

Many of the institutes of the science organizations focus on research in the natural sciences while social sciences and humanities are typically in the domain of universities. When both groups are aggregated in order to be comparable with our sample, it turns out that academics in life sciences are over-represented (5.52 percent) while scientists in natural sciences and social sciences and humanities are slightly under-represented, 2.29 percent and 3.99 percent respectively. The engineering sciences representation most closely matches that of German universities and PROs with a difference of just 0.24 percent. In sum, the observed differences are not too pronounced and we are confident that our sample provides a fair representation of researchers in Germany. ${ }^{7}$

\subsection{Variables and measures}

\section{Dependent variables}

Based on the model outlined in section 2, we alternately employ three dependent

\footnotetext{
${ }^{7}$ In an ideal case, a non-response analysis would be performed which required a control sample with information on scientists' age, gender, discipline and institution. Unfortunately, such information is not available.
} 
variables which are used to measure the scientist's networking activities. The first variable is the total number of conferences the academic reports to have attended on average per year. The second and third variables are subsets of the total number of conferences, i.e. the average number of conferences attended that took place within the European Union, and the average number of conferences attended that took place in the rest of the world. The rationale for using this delineation is the following. Within the European Union, distances from Germany are rather short and the (largely) single European currency, as well as no border controls, lowers the transactions costs on these trips. Moreover, many distinct European professional associations rather than German associations exist and are relevant for scientists' research activities. In this respect, there is almost no difference between domestic and European conference participation. In contrast, conference participation in the rest of the world involves significantly more effort and commitment.

\section{Explanatory variables}

Our explanatory variables include personal and professional attributes of the scientist, passive networking activities and, as an extension, bottlenecks experienced in research activities. Regarding the personal attributes we include the career age, measured as the number of years after the scientist's $\mathrm{PhD}$, as well as gender. Prior literature indicates that faculty behavior might be contingent upon the scientist's gender (e.g., Corley and Gaughan (2005)). Further, experienced scientists might feel less need to seek new collaborations via conference attendance; on the other hand, they might receive greater number of invitations for attendance (Merton (1973)).

The professional attributes relate to the academic's productivity and discipline. In this 
respect, we include the publication stock, i.e. the total number of the scientist's publications $(q)$ up to the year 2002, the beginning of the survey period. This variable is computed based on information from the ISI Web of Science publication database from which the publication information was gathered manually. Research papers are typically the “entrance ticket” to presentations at scientific conferences (see Merton (1973)). At the same time, scientists benefit from input and inspiration received at conferences. The past publication performance that we include in our model is thus clearly exogenous and can be assumed to be unaffected by current networking activities.

Another indicator of scientific productivity is patent applications ( $p$ ). Patents are typically not subject to scientific discussion at conferences but they resemble more the applied side of the scientist's research. Researchers are generally more secretive about their patent applications than they are about their working papers. We thus include the total number of patent applications that the scientist reported to have made since 2002. Apart from this, we include dummy variables to control for whether the scientist reported to have received some sort of extramural research funding from 2002 to 2006 and whether the scientist is tenured. External funding usually provides greater resources for conference participation. More productive scientists are more likely to be senior, tenured, leading a research group and, therefore, are more likely to engage in academic networking. These variables have frequently been employed in other studies explaining the behavior of academics (e.g., Bozeman and Corley (2004), Bozeman and Gaughan (2007)).

Collaboration and networking patterns/practices differ across disciplines. For instance, research in hard sciences is typically conducted in research teams with greater 
need for collaboration than research in disciplines (e.g., social sciences) that mainly use secondary data. Further scientific research that is conducted in a fixed laboratory (compared to field research) is more likely to rely on internal collaboration. To account for these differences, we include dummy variables for life sciences, natural sciences and engineering sciences, with humanities and social sciences being the reference group. The effects of disciplines are widely acknowledged as relevant in a range of faculty activities (e.g., Edler et al. (2011)).

Networking opportunities also depend on institutional factors that are more or less conducive towards passive networking. The first variable we include is therefore a dummy indicating whether the scientist is employed at a university compared to a PRO institute. Scientists employed at universities are likely to have greater leeway in choosing the type of conferences they attend, but might face greater resource constraints than their non-university counterparts (Feller (1990), Goel and Rich (2005)). Moreover, we include a dummy for whether the scientist leads a research group, which could spur greater networking due to a greater number of researchers at the leader's disposal or due to other non-research activities (e.g., recruiting, see Autant et al. (2007)). All variables refer to the time period from 2002 to 2006.

Finally, certain bottlenecks to research activity and hence networking behavior can be identified. Denial of access to others' research via personal communication might induce a researcher to seek more general avenues for information gathering such as conferences. Consequently, we include a dummy variable that takes a value of one if the scientist reported to have requested but been denied access to other scientist's research results, data or artefacts. Moreover, a dummy variable taking a value of one is included if the 
scientist reported having international collaboration activities with other scientists. A lack of international collaboration could be a research bottleneck that a researcher could overcome through active networking by going to conferences. Alternately, collaboration with international co-authors might induce one to attend a greater number of conferences to meet co-authors. Lastly, we include the size of the scientist's peer group, defined as the number of researchers working in similar research fields at the scientist's home institution. Large peer groups enable the formation of internal networks or internal markets for information exchange. While the latter two variables are intended to control for opportunities to receive feedback and stimulus, the first bottleneck variable seeks to control for the restrictiveness of the scientist's research environment in terms of adhering to the norms of open science (Dasgupta and David (1994)). Again, all variables refer to the time period from 2002 to 2006. Table 2 provides an overview of the variables used and how they are defined. 
Table 2: Variable definitions

\begin{tabular}{|c|c|c|}
\hline Variable & Definition/survey question & $\begin{array}{l}\text { Variable } \\
\text { type }\end{array}$ \\
\hline No of conferences (total) & $\begin{array}{l}\text { "On average, at how many conferences and workshops per } \\
\text { year do you present your research results?” (total number) }\end{array}$ & Count \\
\hline No of conferences (EU) & $\begin{array}{l}\text { "On average, at how many conferences and workshops per } \\
\text { year do you present your research results?” (within the EU) }\end{array}$ & Count \\
\hline No of conferences (ROW) & $\begin{array}{l}\text { "On average, at how many conferences and workshops per } \\
\text { year do you present your research results?" (outside the EU) }\end{array}$ & Count \\
\hline Publication stock & $\begin{array}{l}\text { Sum of scientist's publications until } 2002 \text { (inclusive), taken } \\
\text { from ISI Web of Science }\end{array}$ & Count \\
\hline No of patent applications & $\begin{array}{l}\text { "For how many of your inventions have you applied for } \\
\text { patents since 2002?” (number) }\end{array}$ & Count \\
\hline External funding received & $\begin{array}{l}\text { "Have you received third-party funds, including any funds } \\
\text { from the EU framework programme, during the years } 2002 \text { to } \\
\text { 2006?” (yes/no) }\end{array}$ & Dummy \\
\hline Research group leader & $\begin{array}{l}\text { "Do you head a group of scientists autonomously (e.g. chair, } \\
\text { group of junior scientists)?" (yes/no) }\end{array}$ & Dummy \\
\hline Tenured & $\begin{array}{l}\text { "Which kind of employment do you have? Please refer to your } \\
\text { main employment contract which describes your current } \\
\text { position most suitably." (tenured/untenured) }\end{array}$ & Dummy \\
\hline Gender & "What is your sex?" (female=1) & Dummy \\
\hline Career age & $\begin{array}{l}\text { "What is your year of birth?” and "In what year did you } \\
\text { graduate?” }\end{array}$ & $\begin{array}{l}\text { No of } \\
\text { years }\end{array}$ \\
\hline Employed at university & "What kind of institution do you work for?” (university/PRO) & Dummy \\
\hline Social sciences, humanities & "Please indicate your field of research.” & Dummy \\
\hline Life sciences & "Please indicate your field of research." & Dummy \\
\hline Natural sciences & "Please indicate your field of research." & Dummy \\
\hline Engineering sciences & "Please indicate your field of research.” & Dummy \\
\hline No access to others' research & $\begin{array}{l}\text { "Have you requested any research results (such as software, } \\
\text { genetic sequences, data) and/or research materials since } 2002 \\
\text { from other scientists but did not get access?” (yes/no) }\end{array}$ & Dummy \\
\hline International cooperation & $\begin{array}{l}\text { "Have you conducted any joint research projects since 2002?” } \\
\text { (yes, with colleagues from my institution/...from } \\
\text { Germany/...from abroad/no) }\end{array}$ & Dummy \\
\hline Size of peer group & $\begin{array}{l}\text { "How many of your colleagues in your institution work in the } \\
\text { same research area as you?" (number) }\end{array}$ & $\begin{array}{l}\text { No of } \\
\text { peers }\end{array}$ \\
\hline
\end{tabular}

\subsection{Estimation Model}

The dependent variables we use are count data. Because a likelihood ratio test indicates

overdispersion, we use a negative binomial model in all instances. As there are no

indications for excess zeros in the data, we do not estimate a zero inflated model

(Wooldridge (2007)). 


\section{Results}

\subsection{Descriptive statistics}

Table 3 provides summary statistics for the dependent and explanatory variables. It turns out that the scientists in the sample attend on average about seven conferences annually. Only about two of those take place outside the European Union.

\section{Table 3: Summary statistics}

\begin{tabular}{lrrrrr}
\hline Variable & Obs & Mean & Std. Dev. & Min & Max \\
\hline No of conferences (total) & 897 & 6.94 & 4.48 & 1 & 31 \\
No of conferences (EU) & 897 & 5.08 & 3.62 & 0 & 25 \\
No of conferences (ROW) & 897 & 1.86 & 1.64 & 0 & 9 \\
Publication stock & 897 & 36.46 & 59.20 & 0 & 460 \\
No of patent applications & 897 & 0.76 & 2.03 & 0 & 20 \\
External funding received $(d)$ & 897 & 0.85 & 0.36 & 0 & 1 \\
Research group leader $(d)$ & 897 & 0.73 & 0.44 & 0 & 1 \\
Tenured $(d)$ & 897 & 0.82 & 0.38 & 0 & 1 \\
Gender $(1=$ female) & 897 & 0.15 & 0.36 & 0 & 1 \\
Career age (years) & 897 & 18.72 & 9.01 & 0 & 41 \\
Employed at university $(d)$ & 897 & 0.57 & 0.50 & 0 & 1 \\
Employed at PRO $(d)$ & 897 & 0.45 & 0.50 & 0 & 1 \\
Social sciences, humanities $(d)$ & 897 & 0.20 & 0.40 & 0 & 1 \\
Life sciences $(d)$ & 897 & 0.30 & 0.46 & 0 & 1 \\
Natural sciences $(d)$ & 897 & 0.31 & 0.46 & 0 & 1 \\
Engineering sciences $(d)$ & 897 & 0.19 & 0.39 & 0 & 1 \\
No access to others' research $(d)$ & 707 & 0.18 & 0.38 & 0 & 1 \\
International cooperation $(d)$ & 707 & 0.87 & 0.34 & 0 & 1 \\
Size of peer group & 707 & 24.60 & 47.19 & 0 & 400 \\
\hline Note: $(d)$ den & & & & &
\end{tabular}

Note: $(d)$ denotes a dummy variable

Table 4 shows sample means of the explanatory variables differentiated by whether the scientist attends conferences outside the European Union at all. About 200 scientists do not participate in such conferences and the means show remarkable differences between the two groups. Those academics with outside EU conference participation have on average a much larger publication stock and more patent applications. They are also more 
often leading a research group and received external funding. Also, female scientists tend to participate to a lesser degree in conferences outside EU. Geographic differences are also pronounced in some scientific disciplines. While scientists in social sciences and humanities are less often involved in outside EU conferences, scientists in life sciences are involved more often. Moreover, academics with international collaboration partners and with a larger peer group more often participate in outside EU conferences.

Table 4: Mean comparison of explanatory variables by conference participation ROW

\begin{tabular}{|c|c|c|c|}
\hline \multirow[t]{2}{*}{ Variable } & \multicolumn{2}{|c|}{ Conference participation ROW } & \multirow{2}{*}{$\begin{array}{c}\text { T-test on mean } \\
\text { differences }\end{array}$} \\
\hline & yes $(n=688)$ & no $(n=209)$ & \\
\hline Publication stock & 42.60 & 16.23 & $* * *$ \\
\hline No of patent applications & 0.85 & 0.48 & $* *$ \\
\hline External funding received $(d)$ & 0.87 & 0.79 & $* * *$ \\
\hline Research group leader $(d)$ & 0.77 & 0.60 & $* * *$ \\
\hline Tenured $(d)$ & 0.83 & 0.80 & \\
\hline Gender (1=female) & 0.14 & 0.20 & $* *$ \\
\hline Career age (years) & 18.90 & 18.14 & \\
\hline Employed at university $(d)$ & 0.59 & 0.52 & $*$ \\
\hline Employed at PRO $(d)$ & 0.44 & 0.47 & \\
\hline Social sciences, humanities ( $d$ ) & 0.16 & 0.35 & $* * *$ \\
\hline Life sciences $(d)$ & 0.33 & 0.21 & $* * *$ \\
\hline Natural sciences $(d)$ & 0.32 & 0.26 & \\
\hline Engineering sciences $(d)$ & 0.19 & 0.18 & \\
\hline Access denied to other's research $(d)^{\#}$ & 0.18 & 0.17 & \\
\hline Int. collaboration partners $(d)^{\#}$ & 0.89 & 0.79 & $* * *$ \\
\hline Size of peer group ${ }^{\#}$ & 26.79 & 17.44 & $* *$ \\
\hline${ }^{\#} \mathrm{n}=541 / \mathrm{n}=166$ & & & \\
\hline
\end{tabular}

Table 7 in the appendix shows the pairwise correlation coefficients of the explanatory variables as well as the variance inflation factors (VIF). There are no indications of significant multicollinearity in the data. However, Table 7 does provide some interesting insights. One, as expected, the correlation between career age and tenure is positive. 
Two, internal funding is positively related to engineering science, but this is not the case for life sciences and natural sciences. Finally, being research group leader has a greater positive association with external funding, than with either publication stock or patent applications.

\subsection{Estimation results}

The estimation results are presented in Table 5. Although, consistent with most studies using micro-level data, the $\mathrm{R}^{2} \mathrm{~s}$ of various models are rather low, and the chi ${ }^{2} \mathrm{~s}$ are statistically significant in all cases. Recall, that given the nature of the dependent variable(s), it is more meaningful to focus on the signs of the estimated coefficients, rather than their magnitudes. Perhaps it is useful to discuss the findings in terms of the groupings outlined in equation (1) above. Regarding the factors driving active academic networking:

- Personal attributes

Professional experience or career age fails to significantly affect active networking as denoted by conference participation. This is true for total conferences, European conferences and conferences in rest of the world. Gender also generally fails to significantly affect conference participation. However, other things being the same, female German researchers appear relatively less likely to attend non-European conferences. This finding can be viewed in the context of greater family responsibilities shared by females or in terms of safety concerns, ceteris paribus.

- Professional attributes 
The stock of publications $(q)$ consistently and positively affects conference participation across the three dependent variables (i.e., $(\partial z / \partial q)>0)$. Active publishers seem to value the exchange of ideas and other networking benefits from conference participation. However, while external funding also promotes conference participation, the corresponding effect is not significant in the case of ROW conference participation. A plausible explanation is that while external funding might relax some resource constraints for researchers, it is likely to be tied to some constraints that limit travel to geographic proximity, due perhaps to greater exposure benefits to the funding agency.

Further, greater patenting also promotes active networking $((\partial z / \partial p)>0)$. However, the statistical support is relatively weak and nonexistent for ROW conferences. Finally, the tenure status fails to significantly influence networking. This finding is consistent with the notion that un-tenured and tenured researchers might be actively networking for different reasons and tenure status alone is not a significant driver of active networking.

\section{- $\quad$ Passive networking}

As discussed above, a number of factors are included to proxy for passive networking in terms of its bearing on active networking, including (i) university employment; (ii) research group leaders; and (iii) academic discipline. Results from Table 4 show that university employment promotes conference participation in the rest of the world, but not significantly closer to home (EU). This is consistent with the view that universities are relatively more open to broader dissemination of ideas. 
Research group leaders seem to network more, ceteris paribus, across the board. Two main reasons for this might be that research leaders likely have discretionary travel funding at their disposal and that research leaders might be networking for reasons beyond purely research interaction - for example, attending conferences to recruit new researchers.

Our results show interesting networking differences across academic disciplines. Researchers in life sciences and engineering disciplines tend to network more in ROW than closer to home. It could be the case that other less formal communication modes (e.g., seminars) closer to home might be substituting for conference participation in these cases. Natural scientists, on the other hand, are more likely to attend ROW conferences but less likely to attend EU conferences. ${ }^{8}$ It seems that research in this discipline is largely taking place within an international community of scholars with little importance of regional gatherings.

Tying to the title of this article and the main research question, some types of passive academic networking are complementary to active networking while others are substitute. Specifically, passive networking denoted by research group leadership and university employment are complementary to active networking via conference participation. On the other hand, passive networking by being associated with a particular academic discipline, appears to aid some types of

\footnotetext{
8 The effect of EU conferences is also negative and significant for life scientists in one case. Laband and Tollison (2000) provide interesting evidence on the differences across disciplines in assigning property rights from intellectual collaboration.
} 
conference participation in certain disciplines, while discouraging participation in conferences closer to home.

\section{- $\quad$ Publishing bottlenecks}

Finally, of the three publication bottlenecks considered (no access to others' research, (lack of) international cooperation, and (small) size of peer group), peer group size and no access to others' research do not significantly impact conference participation. It is likely the case that in the internet age, denial of research access still enables one to get some information relatively quickly and costlessly and without actively networking. International cooperation seems to spur conference participation across the board, thus a lack of international cooperation does not increase active networking. International collaborating researchers seem to benefit from greater interaction with colleagues.

Overall, publishing bottlenecks as a group generally do not appear to be a hindrance to active networking. 
Table 5: Results of the negative binomial models for active networking (conference visits)

\begin{tabular}{|c|c|c|c|c|c|c|}
\hline & $\begin{array}{c}\text { No of conferences } \\
\text { Total }\end{array}$ & $\begin{array}{c}\text { No of conferences } \\
\text { EU }\end{array}$ & $\begin{array}{c}\text { No of conferences } \\
\text { RoW }\end{array}$ & $\begin{array}{c}\text { No of conferences } \\
\text { Total }\end{array}$ & $\begin{array}{c}\text { No of conferences } \\
\text { EU }\end{array}$ & $\begin{array}{c}\text { No of conferences } \\
\text { RoW }\end{array}$ \\
\hline \multirow[t]{2}{*}{ Publication stock } & $0.002 * * *$ & $0.001^{* * *}$ & $0.002^{* * *}$ & $0.002^{* * *}$ & $0.002^{* * *}$ & $0.002 * * *$ \\
\hline & $(0.000)$ & $(0.000)$ & $(0.000)$ & $(0.000)$ & $(0.000)$ & $(0.001)$ \\
\hline \multirow[t]{2}{*}{ No of patent applications } & $0.017^{* *}$ & $0.018 *$ & 0.018 & 0.015 & 0.013 & 0.022 \\
\hline & $(0.009)$ & $(0.010)$ & $(0.013)$ & $(0.011)$ & $(0.012)$ & $(0.016)$ \\
\hline \multirow[t]{2}{*}{ External funding received $(d)$} & $0.269 * * *$ & $0.306 * * *$ & $0.161 *$ & $0.169 * * *$ & $0.197 * * *$ & 0.094 \\
\hline & $(0.058)$ & $(0.065)$ & $(0.090)$ & $(0.065)$ & $(0.072)$ & $(0.101)$ \\
\hline \multirow{2}{*}{ Research group leader $(d)$} & $0.322 * * *$ & $0.317 * * *$ & $0.333 * * *$ & $0.321 * * *$ & $0.311^{* * *}$ & $0.348 * * *$ \\
\hline & $(0.049)$ & $(0.053)$ & $(0.077)$ & $(0.054)$ & $(0.059)$ & $(0.087)$ \\
\hline \multirow[t]{2}{*}{ Tenured $(d)$} & -0.019 & -0.014 & -0.03 & 0.030 & 0.043 & -0.009 \\
\hline & $(0.056)$ & $(0.062)$ & $(0.085)$ & $(0.064)$ & $(0.071)$ & $(0.098)$ \\
\hline \multirow[t]{2}{*}{ Gender (1=female) } & -0.055 & -0.025 & $-0.147^{*}$ & -0.011 & 0.034 & -0.152 \\
\hline & $(0.055)$ & $(0.060)$ & $(0.087)$ & $(0.063)$ & $(0.068)$ & $(0.103)$ \\
\hline \multirow[t]{2}{*}{ Career age (years) } & -0.001 & 0 & -0.005 & 0.002 & 0.004 & -0.004 \\
\hline & $(0.002)$ & $(0.003)$ & $(0.004)$ & $(0.003)$ & $(0.003)$ & $(0.004)$ \\
\hline \multirow[t]{2}{*}{ Employed at university $(d)$} & 0.038 & -0.009 & $0.162^{* * *}$ & -0.001 & -0.065 & $0.160 * *$ \\
\hline & $(0.041)$ & $(0.045)$ & $(0.062)$ & $(0.048)$ & $(0.052)$ & $(0.074)$ \\
\hline \multirow[t]{2}{*}{ Life sciences $(d)$} & 0.016 & -0.077 & $0.341^{* * *}$ & -0.089 & $-0.173^{* *}$ & $0.179 *$ \\
\hline & $(0.058)$ & $(0.063)$ & $(0.093)$ & $(0.066)$ & $(0.071)$ & $(0.106)$ \\
\hline \multirow[t]{2}{*}{ Natural sciences $(d)$} & -0.093 & $-0.239 * * *$ & $0.356 * * *$ & $-0.154^{* *}$ & $-0.294 * * *$ & $0.252 * *$ \\
\hline & $(0.058)$ & $(0.064)$ & $(0.092)$ & $(0.064)$ & $(0.071)$ & $(0.103)$ \\
\hline \multirow[t]{2}{*}{ Engineering sciences $(d)$} & 0.07 & -0.05 & $0.450 * * *$ & 0.056 & -0.055 & $0.391 * * *$ \\
\hline & $(0.063)$ & $(0.069)$ & $(0.099)$ & $(0.069)$ & $(0.075)$ & $(0.109)$ \\
\hline \multirow[t]{2}{*}{ No access to others' research $(d)$} & & & & 0.076 & 0.085 & 0.052 \\
\hline & & & & $(0.055)$ & $(0.061)$ & $(0.085)$ \\
\hline \multirow[t]{2}{*}{ International cooperation $(d)$} & & & & $0.267 * * *$ & $0.264 * * *$ & $0.278^{* *}$ \\
\hline & & & & $(0.067)$ & $(0.074)$ & $(0.109)$ \\
\hline \multirow[t]{2}{*}{ Size of peer group } & & & & 0.000 & 0.000 & 0.001 \\
\hline & & & & $(0.000)$ & $(0.001)$ & $(0.001)$ \\
\hline \multirow[t]{2}{*}{ Constant } & $1.413^{* * *}$ & $1.161^{* * *}$ & -0.131 & $1.226 * * *$ & $0.977 * * *$ & $-0.299 *$ \\
\hline & $(0.084)$ & $(0.093)$ & $(0.132)$ & $(0.106)$ & $(0.117)$ & $(0.170)$ \\
\hline $\mathrm{R}^{2}$ & 0.031 & 0.028 & 0.035 & 0.034 & 0.032 & 0.037 \\
\hline $\mathrm{N}$ & 897 & 897 & 897 & 707 & 707 & 707 \\
\hline $\mathrm{LR} \mathrm{Chi}^{2}$ & 149.889 & 124.653 & 111.79 & 131.403 & 110.887 & 92.105 \\
\hline P-value & 0.000 & 0.000 & 0.000 & 0.000 & 0.000 & 0.000 \\
\hline
\end{tabular}

Notes: $(d)$ denotes a dummy variable and social sciences and humanities is the reference group. 


\subsection{Robustness checks}

We perform several robustness checks to test the validity of our findings. These include considering nonlineartities and employing alternate estimation techniques.

(a) Including squared term for the scientist's career age (experience)

To account for the possibility that the relationship between active networking and researchers' experience might be nonlinear, the first column in Table 6 in the appendix shows a robustness check with a squared term for the scientist's career age (experience). All the other control variables are the same as those in Table 4. As with the linear term in the previous models, it turns out that there is no significant effect from career age on conference participation. A plausible explanation is that scientists network for various reasons and professional experience does not seem to set them apart in terms of propensity to network.

(b) Including squared term for the number of patent applications

As another robustness check we include the squared number of patent applications. The relationship between both the linear and the squared term turn out to be insignificant which substantiates the linear relationship between patent applications and networking.

(c) Using OLS as the estimation procedure

As a final robustness check, we estimate an OLS regression instead of a negative binomial regression (last column in Table 5). All results turn out to be robust.

\section{Concluding remarks}

Using information from a unique large survey of German researchers this research examines the determinants of academic networking while taking account of the active 
versus passive networking distinction. The extant literature has largely dwelt on overall networking (see Audretsch et al. (2002), Coupé (2003), Stephan (1996)) and the passive versus active networking distinction has mostly been not flushed out (see Faria and Goel (2010) for a notable exception). Other contributions of this work include the role of geographic factors in networking and whether research bottlenecks affect a researcher's propensity to network. Is active networking a substitute or a complement to passive networking? Are the determinants of European conference participation different from conferences in rest of the world?

Results show that some types of passive academic networking are complementary to active networking while others are substitute. Specifically, passive networking denoted by research group leadership and university employment are complementary to active networking via conference participation. Research group leaders seem to have added incentives to network along with greater resources to undertake active networking via conference participation. On the other hand, passive networking by being associated with a particular academic discipline, appear to aid some types of conference participation in certain disciplines, while discouraging participation in conferences closer to home.

Scholarly publications positively affect conference participation, while external funding also promotes conference participation, the corresponding effect is not significant in the case of ROW conference participation. Further, greater patenting also promotes active networking. However, the statistical support is relatively weak and nonexistent for ROW conferences. Finally, the tenure status fails to significantly influence networking. 
Professional experience or career age and gender fail to significantly affect active networking as denoted by conference participation. However, female German researchers appear relatively less likely to attend non-European conferences. The insignificance of experience in terms of its effect on active networking holds when its quadratic term is included as a regressor (Table 6). The findings are also robust to the use of an alternate estimation technique. Overall, publishing bottlenecks (including denial of research access, lack of international cooperation and small peer group size) as a group generally do not appear to be a hindrance to active networking.

Several policy implications can be derived from our study. One implication for academic policy is that, given the differences in some determinants promoting European versus non-European conference participation, researchers obtaining external funding might need internal support for participating in non-European conferences. Assuming that participation in conferences that are more distant to the researcher's home institution also increase the chances to absorb novel knowledge, this support could be granted based on meritocratic funding principles. Also, blanket inducement for active networking might be inferior to discipline-based support. For instance, some researchers tend to network more in their geographic proximity than others. This aspect has implications for the broader diffusion of knowledge and perhaps is already recognized by many institutions. Further, non-university researchers and likely female researchers might need additional inducements to network through conference attendance. Some of this is being done through affirmative action programs. Universities might gain further insights from examining the networking behaviour of research leaders in terms of lessons that might provide for other researchers. Do research leaders actively network more because they 
have more resources at their disposal or because their job description requires them to do so? Moreover, differential conference support for tenured versus non-tenured researchers, as practiced at some institutions, does not seem supported by our findings.

The findings also hold implications for science policy in general. According to aggregate data from the OECD, institutional (“core”) funding of academic research has decreased over the past years. ${ }^{9}$ At the same time, the share of research grants has increased significantly (Auranen and Nieminen (2010)). The decrease in institutional funding could disproportionately affect younger researchers in their ability to attend conferences as an instrument to network and establish collaborations which, over time, would serve to increase their productivity. Given the competition in securing research funding, those younger scholars face disadvantages compared to established researchers with a track record of publications who are able to finance their conference activities through competitive research grants. Although many grant programs are already geared towards young researchers, smaller grants to finance conference visits and shorter research stays abroad would help to alleviate financing constraints as a result of decreased institutional funding at the researchers' home institutions.

In closing we suggest a few extensions to this line of inquiry. A more detailed analysis, subject to availability of corresponding data (especially on some funding and costs), could estimate a system of equations with separate equations determining publications, patents and networking. Obviously, an interesting extension, again subject to data availability, would be to compare the behavior of German researchers studied here to those from other nations.

\footnotetext{
${ }^{9}$ Core funding as a share of civilian government budget appropriations decreased from 26 percent in 1995 to 23 percent in 2007 (OECD (2010)).
} 


\section{References}

Anselin, L., A. Varga, and Z.J. Acs 1997. Entrepreneurship, geographic spillovers, and university research: A spatial econometric approach. Cambridge: Cambridge University Press.

Audretsch, D.B., B. Bozeman, K.L. Combs, M. Feldman, A.N. Link, D.S. Siegel, P. Stephan, G.Tassey, and C. Wessner 2002. The economics of science and technology. Journal of Technology Transfer 27: 155-203.

Audretsch, D.B., and M.P. Feldman 1996. R\&D spillovers and the geography of innovation and production. American Economic Review 86: 630-640.

Auranen, O. and M. Nieminen 2010. University Research Funding and Publication Performance - An International Comparison. Research Policy 39: 822-834.

Autant-Bernard, C., P. Billand, D. Franchisse, and N. Massard 2007. Spatial distance versus spatial distance in R\&D cooperation: Empirical evidence from European collaboration choices in micro and nanotechnologies. Papers in Regional Science 86: 495-519.

BMBF 2008. Bundesbericht Forschung und Innovation. Berlin.

BMBF, (Ed.). 2009. Studie zur Deutschen Beteiligung am 6. Forschungsrahmenprogramm der Europäischen Union. Bonn/Berlin.

Bozeman, B., and E. Corley 2004. Scientists’ collaboration strategies: Implications for scientific and technical human capital. Research Policy 33: 599-616.

Bozeman, B., and M. Gaughan 2007. Impacts of grants and contracts on academic researchers’ interactions with industry. Research Policy 36: 694-707.

Cooper, C.E., S.A. Hamel and S.L. Connaughton. Motivations and obstacles to networking in a university business incubator. Journal of Technology Transfer, in press.

Corley, E., and M. Gaughan 2005. Scientists' participation in university research centers: What are the gender differences. Journal of Technology Transfer 30: 371-381.

Coupè, T. 2004. What do we know about ourselves? On the economics of economics. Kyklos 57: 197-216.

Crane, D., 1965. Scientists at major and minor universities: A study of productivity and recognition. American Sociological Review 30: 699-714. 
Dasgupta, P., and P.A. David 1994. Toward a new economics of science. Research Policy 23: 487-521.

Defazio, D., A. Lockett, and M. Wright 2009. Funding incentives, collaborative dynamics and scientific productivity: Evidence from the EU framework program. Research Policy 38: 293-305.

Edler, J., H. Fier, and C. Grimpe 2011. International scientist mobility and the locus of knowledge and technology transfer. Research Policy, forthcoming.

Ellison, G. 2002. The slowdown of the economics publishing process. Journal of Political Economy 110: 947-993.

Faria, J.R., and R.K. Goel 2010. Returns to networking in academia. Netnomics 11: $103-117$.

Feldman, M.P., A.N. Link, and D.S. Siegel 2002. The economics of science and technology: An overview of initiatives to foster innovation, entrepreneurship, and economic growth. Boston: Kluwer.

Feller, I. 1990. Universities as engines of R\&D-Based economic growth: They think they can. Research Policy 19: 335-348.

Goel, R.K., and D.P. Rich 2005. Organization of markets for science and technology. Journal of Institutional and Theoretical Economics 161: 1-17.

Goyal, S., M.J. van der Leij, and J.L. Moraga-Gonźalez 2006. Economics: An emerging small world. Journal of Political Economy 114: 403-412.

Grimpe, C., and H. Fier 2010. Informal university technology transfer: A comparison between the United States and Germany. Journal of Technology Transfer 35: 637-650.

Hudson, J. 2007. Be known by the company you keep: Citations - quality or chance? Scientometrics 71: 231-238.

Jaffe, A.B., M. Trajtenberg, and R. Henderson 1993. Geographic localization of knowledge spillovers as evidenced by patent citations. Quarterly Journal of Economics 108: 577-598.

Koschatzky, K 2002. Networking and knowledge transfer between research and industry in transition countries: Empirical evidence from the Slovenian innovation system. Journal of Technology Transfer 27: 27-38.

Klamer, A., and H.P. Van Dalen 2002. Attention and the art of scientific publishing. Journal of Economic Methodology 9: 289-315. 
Laband, D.N., and M.J. Piette 1994. Favoritism versus search for good papers: Empirical evidence regarding the behavior of journal editors. Journal of Political Economy, 102: 194-203.

Laband, D.N., and R.D. Tollison 2000. Intellectual collaboration. Journal of Political Economy 108: 632-662.

Macdonald, S., and J. Kam 2007. Ring a ring o' roses: Quality journals and gamesmanship in management studies. Journal of Management Studies 44: 640655.

Medoff, M.H. 2003. Editorial favoritism in economics? Southern Economic Journal 70: 425-434.

Merton, R.K. 1973. The sociology of science. Chicago: University of Chicago Press.

OECD. 2010. Main Science and Technology Indicators. Paris.

Rosa, P., and A. Dawson 2006. Gender and the commercialization of university science: Academic founders of spinout companies. Entrepreneurship and Regional Development 18: 341-366.

Stephan, P.E. 1996. The economics of science. Journal of Economic Literature 34: 1199-1235.

Taylor, S.W., B.F. Fender, and K.G. Burke 2006. Unravelling the academic productivity of economists: The opportunity costs of teaching and service. Southern Economic Journal 72: 846-859.

Thursby, J.G., and M.C. Thursby 2005. Gender patterns of research and licensing activity of science and engineering faculty. Journal of Technology Transfer 30: 343-353.

Wooldridge, J.M. 2007. Econometric analysis of cross section and panel data. Cambridge: MIT press. 


\section{Appendix}

Table 6: Robustness checks

\begin{tabular}{|c|c|c|c|}
\hline & $\begin{array}{c}\text { No of conferences } \\
\text { Total (Negbin) } \\
\end{array}$ & $\begin{array}{c}\text { No of conferences } \\
\text { Total (Negbin) } \\
\end{array}$ & $\begin{array}{c}\text { No of conferences } \\
\text { Total (OLS) } \\
\end{array}$ \\
\hline \multirow[t]{2}{*}{ Publication stock } & $0.002^{* * *}$ & $0.001 * * *$ & $0.010 * * *$ \\
\hline & $(0.000)$ & $(0.000)$ & $(0.003)$ \\
\hline \multirow[t]{2}{*}{ No of patent applications } & $0.017 * *$ & -0.010 & $0.172 * *$ \\
\hline & $(0.009)$ & $(0.019)$ & $(0.070)$ \\
\hline \multirow[t]{2}{*}{ No of patent applications (squared) } & & 0.003 & \\
\hline & & $(0.002)$ & \\
\hline \multirow[t]{2}{*}{ External funding received $(d)$} & $0.267 * * *$ & $0.289 * * *$ & $1.608 * * *$ \\
\hline & $(0.058)$ & $(0.055)$ & $(0.391)$ \\
\hline \multirow[t]{2}{*}{ Research group leader $(d)$} & $0.320 * * *$ & $0.303 * * *$ & $1.796 * * *$ \\
\hline & $(0.049)$ & $(0.045)$ & $(0.331)$ \\
\hline \multirow[t]{2}{*}{ Tenured $(d)$} & -0.026 & -0.009 & -0.037 \\
\hline & $(0.060)$ & $(0.051)$ & $(0.380)$ \\
\hline \multirow[t]{2}{*}{ Gender (1=female) } & -0.056 & -0.047 & -0.262 \\
\hline & $(0.055)$ & $(0.055)$ & $(0.403)$ \\
\hline \multirow[t]{2}{*}{ Career age (years) } & 0.002 & -0.002 & -0.011 \\
\hline & $(0.010)$ & $(0.002)$ & $(0.017)$ \\
\hline \multirow[t]{2}{*}{ Career age (years, squared) } & 0.000 & & \\
\hline & $(0.000)$ & & \\
\hline \multirow[t]{2}{*}{ Employed at university $(d)$} & 0.037 & 0.033 & 0.304 \\
\hline & $(0.041)$ & $(0.041)$ & $(0.307)$ \\
\hline \multirow[t]{2}{*}{ Life sciences $(d)$} & 0.015 & 0.047 & 0.282 \\
\hline & $(0.058)$ & $(0.056)$ & $(0.415)$ \\
\hline \multirow[t]{2}{*}{ Natural sciences $(d)$} & -0.094 & -0.047 & -0.315 \\
\hline & $(0.058)$ & $(0.057)$ & $(0.420)$ \\
\hline \multirow[t]{2}{*}{ Engineering sciences $(d)$} & 0.072 & $0.154^{* *}$ & $1.026^{* *}$ \\
\hline & $(0.063)$ & $(0.062)$ & $(0.468)$ \\
\hline \multirow[t]{2}{*}{ Constant } & $1.391 * * *$ & $1.385 * * *$ & $3.665 * * *$ \\
\hline & $(0.101)$ & $(0.081)$ & $(0.578)$ \\
\hline $\mathrm{R}^{2}$ & 0.031 & 0.031 & 0.123 \\
\hline $\mathrm{N}$ & 897 & 897 & 897 \\
\hline $\mathrm{LR} \mathrm{Chi}^{2} / \mathrm{F}$ & 150.047 & 159.505 & 11.93 \\
\hline P-value & 0.000 & 0.000 & 0.000 \\
\hline
\end{tabular}

Note: $(d)$ denotes a dummy variable and social sciences and humanities is the reference group. Negbin stands for negative binomial. 
Table 7: Correlation table and variance inflation factors

\begin{tabular}{|c|c|c|c|c|c|c|c|c|c|c|c|}
\hline & 1 & 2 & 3 & 4 & 5 & 6 & 7 & 8 & 9 & 10 & 11 \\
\hline 1. Publication stock & 1.00 & & & & & & & & & & \\
\hline 2. No of patent applications & 0.13 & 1.00 & & & & & & & & & \\
\hline 3. External funding received & 0.01 & 0.09 & 1.00 & & & & & & & & \\
\hline 4. Research group leader & 0.11 & 0.12 & 0.27 & 1.00 & & & & & & & \\
\hline 5. Tenured (d) & 0.09 & 0.06 & 0.16 & 0.22 & 1.00 & & & & & & \\
\hline 6. Gender (1=female) & -0.10 & -0.08 & -0.03 & -0.09 & -0.17 & 1.00 & & & & & \\
\hline 7. Career age (years) & 0.29 & 0.05 & 0.00 & 0.13 & 0.41 & -0.13 & 1.00 & & & & \\
\hline 8. Employed at university (d) & 0.06 & -0.10 & 0.09 & 0.30 & 0.12 & -0.03 & 0.16 & 1.00 & & & \\
\hline 9. Life sciences $(d)$ & 0.23 & -0.03 & -0.03 & 0.03 & -0.08 & 0.09 & 0.06 & -0.03 & 1.00 & & \\
\hline 10. Natural sciences $(d)$ & 0.09 & 0.00 & -0.02 & -0.08 & -0.02 & -0.07 & 0.00 & -0.14 & -0.44 & 1.00 & \\
\hline 11. Engineering sciences $(d)$ & -0.12 & 0.23 & 0.09 & 0.09 & 0.11 & -0.13 & -0.05 & -0.03 & -0.32 & -0.32 & 1.00 \\
\hline Variance inflation factor (VIF) & 1.26 & 1.12 & 1.11 & 1.25 & 1.30 & 1.07 & 1.33 & 1.22 & 2.02 & 2.01 & 1.79 \\
\hline
\end{tabular}

Note: $(d)$ denotes a dummy variable 